\title{
Assessment of light intensity and salinity regimes on the element levels of brown macroalgae, Treptacantha barbata: Application of response surface methodology (RSM)
}

\author{
İlknur AK ${ }^{1 *}$ (), Ekrem Cem ÇANKIRILIGİL ${ }^{2}$ (D), Gülen TÜRKER ${ }^{3}$ (D), Onur SEVER ${ }^{4}$
}

\begin{abstract}
In this research, the effect of light intensity and salinity regimes on the element levels of Treptacantha barbata (formerly Cystoseira barbata) was studied, and the elemental compositions of this brown alga collected from wild stocks also compared with

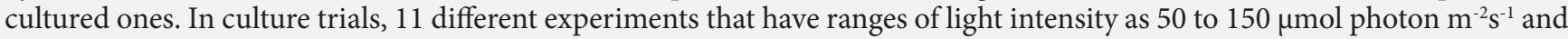
salinity as $24 \%$ to $42 \%$ were designed according to response surface methodology (RSM). Our results show that the element accumulation with changes of light intensity and salinity on the T. barbata was modeled. Most of the elements were affected by the salinity instead of light intensity. All macro and microelements were detected within the recommended dosages and exposure limits. In toxic elements, the least accumulations of $\mathrm{Al}, \mathrm{As}, \mathrm{Cd}$, and $\mathrm{Pb}$ were observed in low light and salinity. Also, the levels of all toxic elements, including trace elements that exceed limits, can be reduced with using these models. The most effective experiment was found as $52.0001 \mu \mathrm{mol}$ photon $\mathrm{m}^{-2} \mathrm{~s}^{-1}$ light and $24.086 \%$ salinity for minimized toxic element accumulation on T. barbata with 0.869 desirability.
\end{abstract}

Keywords: Brown algae; salinity; light intensity; seaweed; Cystoseira barbata.

Practical Application: Control of elemental composition using response surface methodology.

\section{Introduction}

Macroalgae have been used as food, feed, and fertilizers for centuries, although there are differences in regional or agricultural habits (Duinker et al., 2016). While aquatic species such as macroalgae are considered as alternative food sources, the first issue that appears is to ensure food safety (Duinker et al., 2016). Algae take up elements directly from seawater (Sun et al., 2019), and they are the first target affected by elemental pollution in the marine environment (Pfeiffer et al., 2017). Elemental pollution caused by rapid industrialization and an increasing population is one of the most critical factors that directly affect seafood safety (Stankovic et al., 2014). Seaweeds are an excellent source of minerals needed for human metabolism due to their exceptional mineral accumulating capacity (Circuncisão et al., 2018). However, some beneficial trace elements that they have may exceed legal limits defined by authorities with the aforementioned anthropogenic activity (Coenen, 2013). Adequate trace elements monitoring programs of the marine environment should be a priority for the development of better environmental policies for evaluating such risks (Bonanno et al., 2020). With this regard, the Marine Strategy Framework Directive (MSFD) of the European Commission was aimed to get Good Environmental Status (GES) in all marine environments until 2020. According to MSFD, concerning contaminants on the marine environment and seafood, contaminants should below the maximum levels set for the humans, and contaminant levels should be declining over the years even if they were below the legal limits (Law et al., 2010;
Swartenbroux et al., 2010). That is why the elemental composition of marine food sources should be continuously monitored.

Several studies stated that there are various techniques based upon biosorption that aims to remove toxic elements from waters with using biological materials such as algae, bacteria, fungi, and plant residues (Deniz \& Ersanli, 2018). As a new approach, response surface methodology (RSM) having a distinctive feature as less-consuming time compared to other techniques required to optimize any biochemical process (Tabaraki et al., 2014), need sufficient attention for modeling element accumulation in multi-metal systems (Kumar et al., 2016). RSM designed for model building and calculating statistical relationships between the data obtained from experiments and independent variables directly effects the results of the experiments (Alvarez, 2000). RSM applications are already using for the heavy metal removal from wastewaters (Esfandiar et al., 2014; Tajernia et al., 2014) or determining biosorption of some elements in brown algae like Cystoseira indica (Keshtkar et al., 2019), Cystoseira myricaas (Zarei \& Niad, 2017), and Cystoseira trinodis (Salehi et al., 2014). Considering such information, RSM can be used for the reduction of toxic elements along with enhancing beneficial ones in marine algae by manipulating this biochemical process vice versa. Treptacantha barbata is one of the most critical macroalgae species for both the marine environment and the human diet as a promising novel food source. It is an indicator species for 
elemental pollution (Aydın-Önen \& Öztürk, 2017) conjunction with wide range distribution of the species from Eurasia to Africa (Guiry \& Guiry, 2020), the monitoring of this species becomes particularly important. The environmental conditions limit independent variables that can affect biosorption. Among them, salinity and light intensity are the most significant factors for the distribution of this algae. By interfering with the levels of salinity and light intensity on the prevailing culture procedure, it is possible that monitoring the elemental composition of this brown seaweed.

In this study, the effects of light intensity and salinity regimes on the element accumulation in Treptacantha barbata were studied. The Box-Behnken design of response surface methodology (RSM) was used to determine experimental trials. The accumulation of elements of T. barbata was formulated with RSM application. Also, the elemental composition of wild stock was determined and modeled along with the effects of light intensity and salinity.

\section{Material and methods}

\subsection{Study material}

Brown Alga Treptacantha barbata (Stackhouse) Orellana \& Sansón, 2019 (formerly known as Cystoseira barbata) was used as the main material. Thallus of $T$. barbata were collected from the shores of the Dardanos district in Çanakkale, Turkey $\left(40^{\circ} 4^{\prime} 38.47^{\prime \prime} \mathrm{N}\right.$; $\left.26^{\circ} 21^{\prime} 35.08^{\prime \prime} \mathrm{E}\right)$. Samples were stored in sea water-filled bottles and transferred immediately to the laboratory. After the epiphytes and the other organisms were cleaned, thallus were divided into three different groups and had been adapted to the salinity conditions for one week. The thallus of $T$. barbata has used stock cultures, which were grown in $50 \mathrm{~L}$ plexiglas tanks having UV sterilized seawater at $20^{\circ} \mathrm{C}, 100 \mu \mathrm{mol}$ photon $\mathrm{m}^{-2} \mathrm{~s}^{-1}$. Experiments were conducted at $3 \mathrm{~L}$ cylindrical glass bottles (15 $\mathrm{cm}$ in diameter). Artificial seawater, which is a culture medium in all groups, was prepared according to literature (Guillard, 1975). In experiments, cultures were aerated by bubbling air. The temperature and $\mathrm{pH}$ values of the cultures were monitored with $\mathrm{pH}$ meter (Hanna, HI8314). The light intensity was measured by LI-250 light meter (LiCOR, USA).

\subsection{Experimental design}

In this study, the effects of two independent factors, just as light intensity and salinity on the element accumulation in Treptacantha barbata, were evaluated. The Box-Behnken design of response surface methodology (RSM) was used to determine experimental trials. The maximum and minimum values of the factors mentioned above were specified according to optimum growth ranges, and environmental conditions of the T. barbata. The upper or lower values of these factors cause stress on algae and inhibit growth. The light intensity was selected as ranging from 50 to $150 \mu \mathrm{mol}$ photons $\mathrm{m}^{-2} \mathrm{~s}^{-1}$ and salinity was selected as ranging from $24 \%$ to $42 \%$. Eleven experiments having differences in the combination of these factors and suggested by the Box-Behnken design were run. All experiments were replicated three times $(n=3)$. At the end of the experiments, the elemental compositions of experimental groups were determined.

\subsection{Element analysis}

The element compositions of T. barbata were determined according to the method of the Nordic Committee on Food Analysis (method 18) (Nordisk Metodikkomité for Næringsmidler, 2007). To avoid secondary contamination and ensure standardization between element analyses, the procedures recommended by the 8th and 9th task group of Marine Strategy Framework have been carried out (Law et al., 2010; Swartenbroux et al., 2010). Samples were analyzed via ICPAES (Varian Liberty AX Sequential ICP-AES). The analyzed elements were silver $(\mathrm{Ag})$, aluminum $(\mathrm{Al})$, arsenic $(\mathrm{As})$, boron (B), calcium (Ca), cadmium (Cd), cobalt (Co), chromium $(\mathrm{Cr})$, copper $(\mathrm{Cu})$, iron $(\mathrm{Fe})$, potassium $(\mathrm{K})$, magnesium $(\mathrm{Mg})$, manganese (Mn), molybdenum (Mo), sodium $(\mathrm{Na})$, nickel $(\mathrm{Ni})$, phosphorus $(\mathrm{P})$, lead $(\mathrm{Pb})$, antimony $(\mathrm{Sb})$, selenium $(\mathrm{Se})$, tin $(\mathrm{Sn})$, and zinc $(\mathrm{Zn})$. Finally, results were compared with the standards (VH6 lab single element atomic absorption CRM) and calculated as parts per million (ppm). All analyses were carried out as three parallel and three replicates.

\subsection{Data evaluation}

Differences between elemental compositions of the trials were evaluated by one-way analysis of variance (ANOVA) after the normality and homogeneity were specified with AndersonDarling test and Levene's test, respectively. In the evaluation of the effects of Box-Behnken design, the obtained data were written in response columns in the design matrix and evaluated with Design Expert 7.15 software. All models were formulated individually, and surface response plots were given. Formulations 1 and 2 were given below:

$$
\begin{aligned}
& y=\beta_{0}+\sum \beta_{i} X_{i}(\text { Linear model }) \\
& y=\beta_{0}+\sum \beta_{i} X_{i}+\sum \beta_{i j} X_{i} X_{j}(2 F I \text { model })
\end{aligned}
$$

Where $y$ is the response; $\beta_{0}$ is the regression intercept; $X$ symbols are independent variables; $\beta_{\mathrm{i}}$ is coefficient of the linear parameters; and $\beta_{\mathrm{ij}}$ is coefficient of interaction between factors (Davarnejad et al., 2018).

Coded values were used in equation terms. The equation in terms of coded factors can be used to make predictions about the response for given levels of each factor. High levels of the factors are coded as +1 , and the low levels of the factors are coded as -1 . The coded equation is useful for identifying the relative impact of the factors by comparing the factor coefficients. Optimized values were suggested to get minimal values of toxic elements. In optimization, $\mathrm{Al}, \mathrm{As}, \mathrm{Cd}$, and $\mathrm{Pb}$ were selected for getting minimum along with other elements selected as in the range, except for elements having insignificant accumulation models. Data on the insignificant models were not used in optimization.

\section{Results and discussion}

According to our results, sodium $(\mathrm{Na})$, calcium $(\mathrm{Ca})$, potassium $(\mathrm{K})$, magnesium $(\mathrm{Mg})$, phosphorus $(\mathrm{P})$, and iron (Fe) were detected as highest in T. barbata collected from 
Çanakkale strait, respectively. It is a known fact that macroalgae species are abundant in terms of $\mathrm{Ca}, \mathrm{Mg}, \mathrm{Na}, \mathrm{P}$, and $\mathrm{K}$ (Rodrigues et al., 2015). Macroalgae species are good sources of iron (García-Casal et al., 2007). Likewise, in our research, iron was detected in high amounts and evaluated within the macro group for better display on the optimization process. Similar elemental compositions were found in Sargassaceae family (Kravtsova et al., 2014; Vizetto-Duarte et al., 2016), and the different algae species which were collected from nearby locations (Berik \& Çankırılıgil, 2019).

T. barbata is also a good source of trace elements (Bonanno \& Orlando-Bonaca, 2018; Vizetto-Duarte et al., 2016), which are needed for human metabolism within optimum values (Circuncisão et al., 2018). According to the results; boron (B), and manganese $(\mathrm{Mn})$, were found the highest trace elements and followed by chromium $(\mathrm{Cr})$, tin $(\mathrm{Sn})$, zinc $(\mathrm{Zn})$, nickel $(\mathrm{Ni})$, copper $(\mathrm{Cu})$, and molybdenum (Mo), respectively. Aydın-Önen \& Öztürk (2017) stated that T. barbata collected from the Aegean Sea shows high bioconcentration factor for manganese and zinc. Similarly, chromium was found high in T. barbata. Several studies stated that this seaweed could absorb a high amount of chromium and nickel from the seawater (Niemiec et al., 2015; Simeonova \& Petkova, 2007). Although tin known as an essential trace element for some animals, the necessity for the human is still unclear (TomzaMarciniak et al., 2019). Tin in the marine environment is usually found in the form of organic tributyl-tin (TBT) complex (Feldstein et al., 2003), which is mostly used for in paints for ships due to their antifouling feature (Takahashi et al., 2000). Considering the sampling area in the Çanakkale Strait, which is amongst the most important trade routes (Başar, 2010), it can be said that this activity may cause the tin content of the marine alga. Low copper concentration in the T. barbata may be a reason for the low molybdenum level as well. In living organisms, the biologically active form of molybdenum is found as the molybdenum cofactor (Moco), and the biosynthesis of this cofactor requires proteins, iron, ATP, and copper (Mendel, 2013). Moreover, cobalt (Co), selenium (Se), silver (Ag), and antimony $(\mathrm{Sb})$ were found just slightly higher than the detection limits, respectively. Cobalt found very low concentrations in the Mediterranean Sea due to the marine redox process (Swanner et al., 2014), thereby it found very low in the algae as well. Fish, shellfish, and other aquatic animals are rich in terms of selenium (Calatayud et al., 2012; Liu et al., 1987; Wang et al., 2019), whereas most of the plants are selenium sensitive and non-accumulators (Wang et al., 2019). Besides, Liu et al. (1987) stated that algae species have little selenium concentrations compared to other aquatic species. Silver and antimony, which are occurring natural metalloids, can be found in small amounts in the environment, but the amount of those elements can rise with the industrial activities (HiriartBaer et al., 2006; Ungureanu et al., 2018). In this research, levels of silver and antimony in the T. barbata were found very low.

Mercury concentration of the T. barbata found very low due to algae are primary producers, and mercury risk exists in higher predators. Similarly, cadmium and lead were found below the legal limits described by the authorities (Food and Agriculture Organization of the United Nations, 2007, 2011).
Although there was no limitation described to aluminum contaminations on the fish and other seafood, the European Food Safety Authority (2013) stated that aluminum exposure should not exceed $1 \mathrm{mg} \mathrm{kg}^{-1}$ weekly for humans. The toxicological and biochemical activity of the arsenic depends on its chemical structure (Mushtaque \& Chowdhury, 2004). Organic arsenic compounds are accepted as non-toxic for the living organisms (Oya-Ohta et al., 1996; Pergantis et al., 2000). Ma et al. (2018) were investigated 282 macroalgae species and stated that brown algae have the highest arsenic, which is consisted of both organic and inorganic forms.

It is a clear fact that T. barbata collected from Çanakkale Strait rich in terms of macro and microelements. This elemental richness is related to algae's capacity to retain inorganic compounds accounting for up to $36 \%$ of dry matter in some species (Lordan et al., 2011). Although, the high presence of minerals on the algae is an essential advantage for human nutrition and human health (Mišurcová et al., 2011), excessive trace elements (or microelements) concentrations are harmful to all organisms. Thus, research about on elemental composition of the macroalgae can be show alterations even if they carried out on the same species. In our study, all elements were detected within the recommended dosage stated by the Reference Nutrient Intake (British Nutrition Foundation, 2016; Mišurcová et al., 2011). However, these values can be exceeded limits, especially in some aquaculture implementations. Therefore, we also evaluated the element accumulation on T. barbata in our study. According to results, levels of $\mathrm{Ag}, \mathrm{Al}, \mathrm{B}, \mathrm{Co}, \mathrm{Cu}, \mathrm{Fe}, \mathrm{K}, \mathrm{Mg}, \mathrm{Mn}, \mathrm{Mo}, \mathrm{Na}, \mathrm{Ni}$, $\mathrm{P}, \mathrm{Se}$, and $\mathrm{Zn}$ were detected as the lowest in the wild compared to culture trials. In culture experiments, an artificial seawater medium was used to provide nutrients such as macronutrients, trace metals, anhydrous, and hydrous salts needed for the species' growth. Thus, the elemental composition of the T. barbata obtained from culture trials were differ by wild ones in parallel with element supplementation. Only elements that were found highest in the wild specimens were determined as $\mathrm{Ca}, \mathrm{Cr}, \mathrm{Sn}$, and toxic ones such as $\mathrm{As}, \mathrm{Cd}$, and $\mathrm{Hg}$. All of those elements were not added with artificial seawater medium, and that is why their levels reduced in culture trials, except $\mathrm{Ca}$, which is one of the components of the artificial seawater. Despite calcium supplementation, the relatively low amount of calcium detected in the samples can be explained by photosynthesis. In the algal growth, algae specimens use saturated $\mathrm{CO}_{2}$ from the environment as well as light to produce carbohydrates needed for the growing, and they release $\mathrm{O}_{2}$ into the water in consequence of the photosynthesis process (Beer \& Koch, 1996; Sant \& Ballesteros, 2020). In the meantime, some amounts of $\mathrm{CO}_{2}$ is also released to the environment due to respiration (Raven \& Beardall, 2003). If there is an adequate light source, a balance can be achieved between the amount of oxygen and carbon dioxide in the water, but the $\mathrm{CO}_{2}$ may increase when the light is cut off (Larkum \& Wood, 1993; Zou et al., 2011). Excessive $\mathrm{CO}_{2}$ in the water can be precipitated as calcium carbonate $\left(\mathrm{CaCO}_{3}\right)$ by binding with Ca (Raven \& Beardall, 2003). This biochemical process can be the reason to low Ca levels of the cultured specimens compared to wild algae. When we examine levels of elements according to culture trials, it is shown that the level of each element was changed at different rates by salinity and light intensity. 
Table 1. Elemental composition of Treptacantha barbata obtained from wild and culture trials.

\begin{tabular}{|c|c|c|c|c|c|c|}
\hline $\begin{array}{c}\text { Elements } \\
\text { (ppm) }\end{array}$ & Wild & $\mathrm{T} 1$ & $\mathrm{~T} 2$ & T3 & $\mathrm{T} 4$ & $\mathrm{~T} 5^{*}$ \\
\hline $\mathrm{Ca}$ & $19810.41 \pm 15.78^{\mathrm{a}}$ & $17247.29 \pm 15.85^{\mathrm{f}}$ & $17963.89 \pm 13.55^{\mathrm{b}}$ & $17636.49 \pm 5.64^{\mathrm{d}}$ & $17710.22 \pm 11.69^{c}$ & $17419.28 \pm 9.67^{\mathrm{e}}$ \\
\hline $\mathrm{Fe}$ & $116.86 \pm 1.42^{\mathrm{e}}$ & $323.82 \pm 1.21^{\mathrm{a}}$ & $310.64 \pm 1.14^{\mathrm{b}}$ & $227.98 \pm 1.14^{\mathrm{c}}$ & $225.32 \pm 1.08^{c}$ & $177.33 \pm 1.10^{\mathrm{d}}$ \\
\hline $\mathrm{Mg}$ & $5587.75 \pm 9.84^{\mathrm{f}}$ & $7609.25 \pm 7.32^{\mathrm{a}}$ & $7575.33 \pm 6.08^{\mathrm{b}}$ & $7428.15 \pm 7.32^{c}$ & $7312.80 \pm 5.21^{\mathrm{d}}$ & $7136.10 \pm 4.12^{\mathrm{e}}$ \\
\hline $\mathrm{Na}$ & $20638.00 \pm 28.56^{\mathrm{f}}$ & $24563.33 \pm 26.56^{\mathrm{d}}$ & $23104.90 \pm 27.29^{\mathrm{e}}$ & $31107.50 \pm 25.21^{\mathrm{a}}$ & $30156.63 \pm 25.13^{b}$ & $24625.17 \pm 27.11^{c}$ \\
\hline B & $19.68 \pm 0.38^{\mathrm{f}}$ & $40.80 \pm 0.22^{\mathrm{b}}$ & $42.56 \pm 0.13^{\mathrm{a}}$ & $33.68 \pm 0.13^{\mathrm{d}}$ & $35.12 \pm 0.13^{c}$ & $33.06 \pm 0.14^{\mathrm{e}}$ \\
\hline Co & $0.09 \pm 0.01^{\mathrm{d}}$ & $0.19 \pm 0.01^{\mathrm{b}}$ & $0.17 \pm 0.02^{\mathrm{b}}$ & $0.22 \pm 0.02^{\mathrm{ab}}$ & $0.25 \pm 0.01^{\mathrm{a}}$ & $0.12 \pm 0.01^{\mathrm{c}}$ \\
\hline $\mathrm{Cr}$ & $2.60 \pm 0.02^{\mathrm{a}}$ & $1.63 \pm 0.02^{\mathrm{b}}$ & $1.18 \pm 0.02^{\mathrm{c}}$ & $0.99 \pm 0.03^{\mathrm{e}}$ & $1.02 \pm 0.01^{\mathrm{e}}$ & $1.10 \pm 0.01^{\mathrm{d}}$ \\
\hline $\mathrm{Cu}$ & $0.43 \pm 0.09^{\mathrm{d}}$ & $0.89 \pm 0.02^{\mathrm{a}}$ & $0.78 \pm 0.01^{\mathrm{b}}$ & $0.69 \pm 0.02^{c}$ & $0.72 \pm 0.01^{\mathrm{c}}$ & $0.47 \pm 0.03^{\mathrm{d}}$ \\
\hline Mn & $5.26 \pm 0.09^{f}$ & $12.60 \pm 0.07^{\mathrm{a}}$ & $11.16 \pm 0.05^{\mathrm{b}}$ & $10.52 \pm 0.06^{c}$ & $9.63 \pm 0.03^{\mathrm{d}}$ & $9.06 \pm 0.04^{\mathrm{e}}$ \\
\hline Sn & $0.80 \pm 0.09^{\mathrm{a}}$ & $0.52 \pm 0.02^{\mathrm{b}}$ & $0.50 \pm 0.04^{\mathrm{b}}$ & $0.28 \pm 0.01^{\mathrm{c}}$ & $0.28 \pm 0.01^{\mathrm{c}}$ & $0.55 \pm 0.03^{\mathrm{b}}$ \\
\hline $\mathrm{Zn}$ & $0.79 \pm 0.08^{\mathrm{d}}$ & $1.58 \pm 0.05^{\mathrm{a}}$ & $1.55 \pm 0.04^{\mathrm{a}}$ & $1.31 \pm 0.04^{\mathrm{b}}$ & $1.32 \pm 0.02^{\mathrm{b}}$ & $1.24 \pm 0.03^{c}$ \\
\hline $\mathrm{Al}$ & $238.59 \pm 1.59^{c}$ & $240.35 \pm 1.68^{c}$ & $239.56 \pm 1.62^{c}$ & $245.19 \pm 1.79^{b}$ & $250.12 \pm 1.73^{\mathrm{a}}$ & $250.51 \pm 1.86^{\mathrm{a}}$ \\
\hline As & $110.91 \pm 1.82^{\mathrm{a}}$ & $88.40 \pm 1.21^{\mathrm{d}}$ & $88.56 \pm 1.23^{\mathrm{d}}$ & $98.87 \pm 1.01^{b c}$ & $99.56 \pm 0.94^{\mathrm{b}}$ & $97.28 \pm 1.07^{c}$ \\
\hline $\mathrm{Cd}$ & $1.45 \pm 0.26^{\mathrm{a}}$ & $0.08 \pm 0.01^{\mathrm{c}}$ & $0.08 \pm 0.01^{c}$ & $0.14 \pm 0.01^{\mathrm{b}}$ & $0.13 \pm 0.01^{\mathrm{b}}$ & $0.05 \pm 0.01^{\mathrm{d}}$ \\
\hline $\mathrm{Hg}$ & $0.03 \pm 0.01^{\mathrm{a}}$ & $0.01 \pm 0.01^{\mathrm{b}}$ & $0.01 \pm 0.01^{\mathrm{b}}$ & $0.01 \pm 0.01^{\mathrm{b}}$ & $0.01 \pm 0.01^{\mathrm{b}}$ & $0.01 \pm 0.01^{\mathrm{b}}$ \\
\hline $\mathrm{Pb}$ & $0.50 \pm 0.02^{\mathrm{b}}$ & $0.54 \pm 0.02^{\mathrm{a}}$ & $0.55 \pm 0.02^{\mathrm{a}}$ & $0.52 \pm 0.02^{\mathrm{ab}}$ & $0.50 \pm 0.02^{\mathrm{b}}$ & $0.45 \pm 0.01^{\mathrm{c}}$ \\
\hline
\end{tabular}

${ }^{*}$ T1: Trial 1, T2: Trial 2, T3: Trial 3, T4: Trial 4, T5: Trial 5. Data were expressed as Mean \pm SD $(n=3)$. Means with different superscript letters in a line are significantly different $(\mathrm{p}<0.05)$.

The elemental composition of the specimens of culture trials was shown in Table 1.

To better understand the accumulation of each element in T. barbata by salinity and light intensity, the obtained results modeled considering applied levels of the independent variables. Alternative model types such as linear, two-factor interaction (2FI), quadratic, and cubic models were analyzed automatically with Design-Expert software to achieve an insignificant lack of fit and maximizing adjusted $\mathrm{R}$-squared $\left(\mathrm{R}^{2}\right)$ values, thereby the most significant model suggested by the software was applied to each element. According to statistical analysis, while the linear model was applied for $\mathrm{Al}, \mathrm{As}, \mathrm{B}, \mathrm{Cd}, \mathrm{Co}, \mathrm{Cu}, \mathrm{Fe}, \mathrm{Hg}, \mathrm{K}, \mathrm{Mg}, \mathrm{Mn}$, $\mathrm{Mo}, \mathrm{Na}, \mathrm{Ni}, \mathrm{Se}, \mathrm{Sn}$ and $\mathrm{Zn}, 2 \mathrm{FI}$ model was applied for $\mathrm{Ag}, \mathrm{Ca}$, $\mathrm{Cr}, \mathrm{P}, \mathrm{Pb}$, and $\mathrm{Sb}$. Analyses of variance for element accumulation models of T. barbata shown in Table 2. The F-value of the model implies the model is significant or not, which is decided by the software considering the F-value and Prob $>$ F value together. Prob $>\mathrm{F}$ is the $\mathrm{p}$-value for the whole model test, and it shows the probability that F-value is caused by noise. Considering these values of models (Table 2); while models of Al, As, B, Ca, $\mathrm{Cd}, \mathrm{Cr}, \mathrm{Fe}, \mathrm{K}, \mathrm{Mn}, \mathrm{Na}, \mathrm{Ni}, \mathrm{P}, \mathrm{Pb}, \mathrm{Sb}, \mathrm{Se}, \mathrm{Sn}$, and $\mathrm{Zn}$ were found significant, $\mathrm{Ag}, \mathrm{Co}, \mathrm{Cu}, \mathrm{Hg}, \mathrm{Mg}$, and Mo models were found as not significant. The insignificant models have $11.56 \%, 10.31 \%$, $25.12 \%, 12.85 \%, 6.93 \%$, and $17.85 \%$ chance that an F-value this large could occur due to noise for the $\mathrm{Ag}, \mathrm{Co}, \mathrm{Cu}, \mathrm{Hg}, \mathrm{Mg}$, and Mo respectively. Values of "Prob > F" less than 0,0500 indicate model terms just as light intensity (A), salinity (B), and interaction of light intensity and salinity $(\mathrm{AB})$ accepted as significant. According to our results, light intensity (A) and salinity (B) detected as significant in $\mathrm{Cr}, \mathrm{Mn} \mathrm{Pb}$, and Se models. Interaction of light intensity and salinity $(\mathrm{AB})$, which exists only 2FI models, were also found significant in the $\mathrm{Cr}$ model, while it was found not significant in the $\mathrm{Pb}$ model.

Salinity (B) was found significant, whereas light intensity (A) was found insignificant in the models of $\mathrm{Al}, \mathrm{As}, \mathrm{B}, \mathrm{Cd}, \mathrm{Fe}$, $\mathrm{K}, \mathrm{Na}, \mathrm{Ni}, \mathrm{Sn}$, and $\mathrm{Zn}$. In the P model, the significance of the terms was found similar to the element, as mentioned earlier models. In addition to those, the interaction of the terms (AB) was specified as significant instead of insignificant light (A). On the contrary, only insignificant salinity (B) model terms were observed in $\mathrm{Ca}$ and Se models among all models. They also have significant light intensity $(\mathrm{A})$ and interaction of light intensity and salinity $(\mathrm{AB})$ terms (Table 2 ).

The results were evaluated in the numerical optimization option in Design Expert 7.15 software. The sodium model was not used in the optimization procedure, although it was found a significant model as expected due to sodium addition to adjusting salinity in experiments. So, to get more concise results, sodium was not evaluated with other significant models just as insignificant ones. In optimization, significant element models such as Al, As, B, Ca, Cd, Cr, Fe, K, Mn, Ni, P, Pb, Sb, $\mathrm{Se}, \mathrm{Sn}$, and $\mathrm{Zn}$ were selected as "in the range" choice except for $\mathrm{Na}$, whereas all significant toxic elements models. $\mathrm{Al}, \mathrm{As}, \mathrm{Cd}$ 
Table 2. Analyses of variance for element accumulation models of Treptacantha barbata.

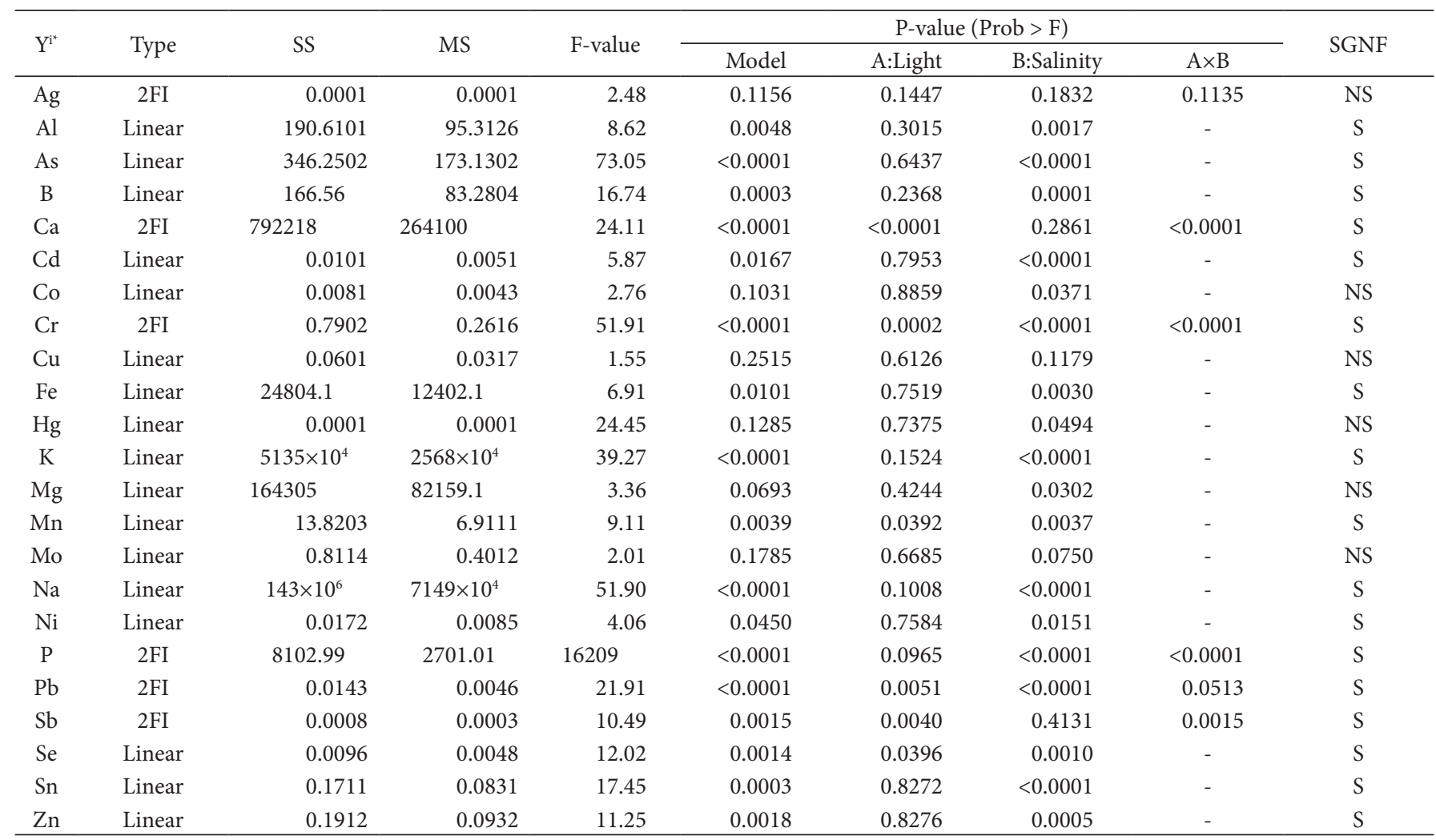

${ }^{*} \mathrm{Y}^{\prime}$ : Response; SS: Sum of squares; MS: Mean squares; SGNF: Significance; S: Significant; NS: Not significant; F-value: Variance between the means; P-value: The probability of obtaining results.

and $\mathrm{Pb}$ were selected as "minimum" choice in the numerical optimization section on the Design Expert 7.15 to get minimum toxic element accumulation along with moderate trace ones. All insignificant models of $\mathrm{Ag}, \mathrm{Co}, \mathrm{Cu}, \mathrm{Hg}, \mathrm{Mg}$, and Mo were not taken into account in optimization as well as $\mathrm{Na}$ model. According to optimizations, amongst 12 solutions offered by Design Expert, the most effective one having the highest desirability $(0.869)$ is determined as $52.0001 \mu$ mol photon $\mathrm{m}^{-2}$ $\mathrm{s}^{-1}$ light and $24.086 \%$ salinity for minimized toxic element accumulation on T. barbata. Finally, $3 \mathrm{~d}$ response surface plots of significant models were shown as macro, micro, and toxic elements in Figure 1.

In macroalgae, the elemental composition of the species is directly related to species and the environment (Bonanno \& Orlando-Bonaca, 2018). Our study shows that it is possible to manipulate the element composition of algae by light and salinity, considering the accumulation pattern of selected elements. With RSM application, algae can be transformed into more nutritious compared to wild forms. According to the results of our study, T. barbata has calcium, sodium potassium, magnesium, iron, and some trace elements in high amounts such as boron, zinc, manganese. Calcium was the most crucial element (MacArtain et al., 2007), and brown seaweeds accumulated tend to accumulate higher concentrations of sodium and potassium than green seaweeds (Circuncisão et al., 2018). Iron is an essential element for humans because it participates in fundamental cell functions (Mišurcová et al., 2011). Iron deficiency is a nutritional disorder that can be affected in the development of the neuropsychomotor systems (Rodrigues et al., 2015). Boron is needed to bone growth, protecting the nervous system, hormone secretion, and it is associated with reducing cardiac diseases and some cancer types (Nielsen, 2014). With such benefits, boron abounds in marine algae (Dembitsky et al., 2002). T. barbata also has manganese and zinc, which are essential trace elements for human metabolism as well as boron. Manganese is an essential trace element which is involved in the metabolism of protein, lipid, and carbohydrate, and performs as various enzymes cofactors (Mišurcová et al., 2011). Zinc is an antioxidant, regulates immune response, and it is necessary for growth and development (Salgueiro et al., 2000).

Despite such benefits of rich element composition, macroalgae can also accumulate some toxic elements such as arsenic (As), aluminum $(\mathrm{Al})$, cadmium $(\mathrm{Cd})$, lead $(\mathrm{Pb})$, and mercury $(\mathrm{Hg})$ which can represent a health risk for the people (Circuncisão et al., 2018). Mercury is accumulating in the marine food chain and leading to an elevated concentration in predator species (Spada et al., 2012). Cadmium and lead contaminations are causing long term toxic effects with accumulating in organisms (Baloch et al., 2020). Aluminum, which is a neurodegenerative element causes serious brain diseases such as Parkinson and Alzheimer's disease (Iglesias-González et al., 2017; Yokel et al., 1994). In view of the results, it is possible to avoid such risks by reducing these toxic elements with RSM application. 

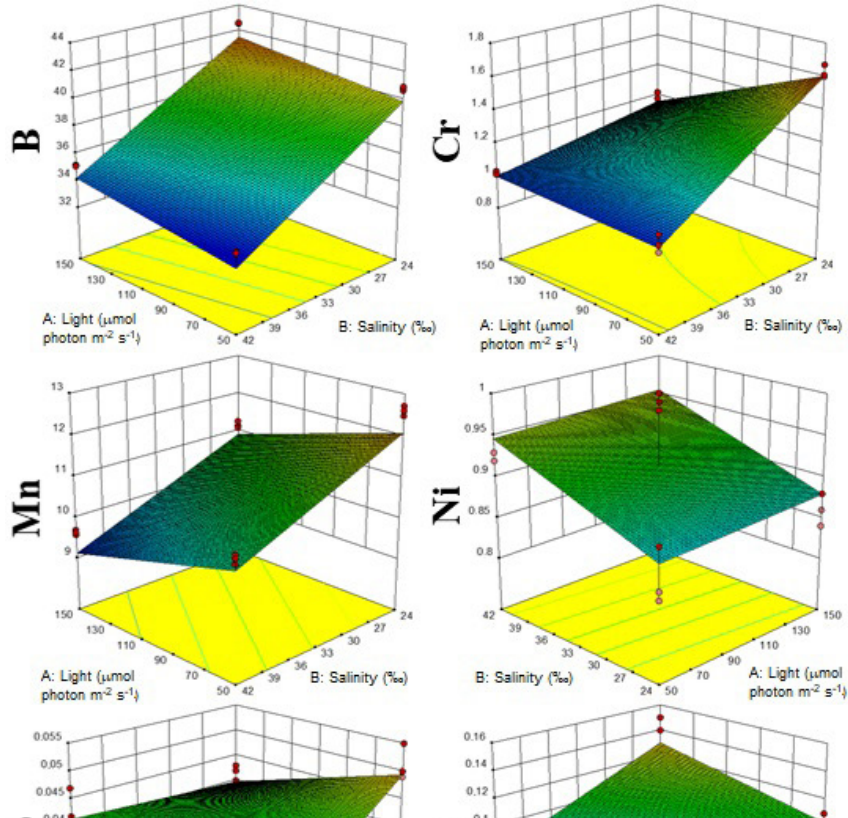

\section{क}
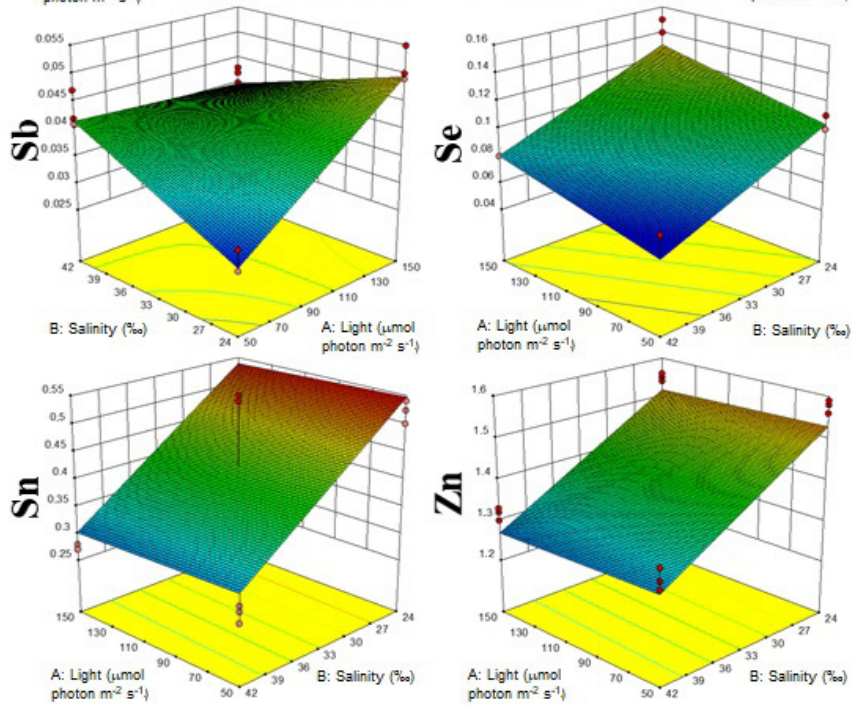
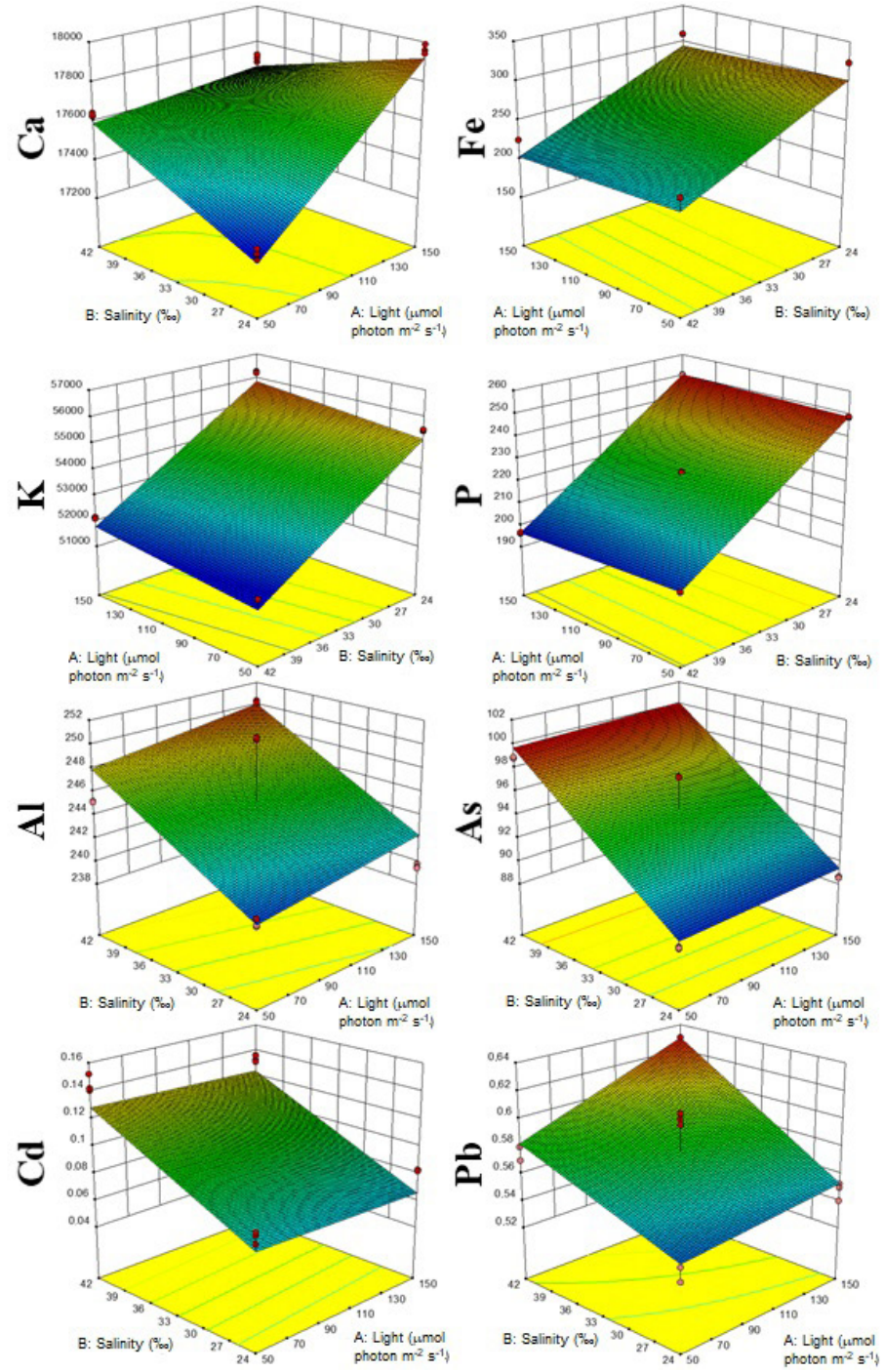

Figure 1. Response surface plots for the accumulation of elements in Treptacantha barbata.

\section{Conclusion}

Seaweeds are one of the most crucial vegetable sources of minerals. According to our results, T. barbata can be used as mineral sources with rich macro and microelements as well as low content of toxic elements. Besides, the influence of light intensity and salinity on the elemental composition of T. barbata culture was determined. According to element accumulation models, most of the elements were affected by the salinity instead of light intensity. These preliminary results will shed light on further studies, especially on the manipulation of element accumulations of macroalgae. The ability of element manipulation on macroalgae species is vital for both environmental studies and seafood science. Macroalgae species are already using as heavy metal removals in polluted water sources. With RSM application, they can be used as metal adsorbents more effectively considering different accumulation patterns of each element on the T. barbata, which is determined in this study. Inversely, macroalgae species can be transformed into more nutritious food sources with RSM methodology. It is possible to obtain macroalgae that are rich in terms of beneficial trace elements, whereas containing less toxic elements. All macro and microelements were detected within the recommended dosages and exposure limits stated by authorities. As the element analysis was done with ICP, only the amount of the elements in the algae was determined. Even if these elements are detected below the limit values, few compounds which are toxic forms of some trace elements can be dangerous. The levels of all toxic elements, including trace elements that exceed limits, can be reduced by using these models. Moreover, T. barbata has high amounts of arsenic compounds which caused by organic arsenoriboses. However, the mechanism of the arsenoribose accumulation on the brown macroalgae is still unknown. Future elemental studies should focus on understanding this mechanism, and the RSM application can help achieve this goal.

\section{References}

Alvarez, L. V. (2000) Design optimization based on genetic programming. UK: Department of Civil and Environmental Engineering University of Bradford. 
Aydın-Önen, S., \& Öztürk, M. (2017). Investigation of heavy metal pollution in eastern Aegean Sea coastal waters by using Cystoseira barbata, Patella caerulea, and Liza aurata as biological indicators. Environmental Science and Pollution Research International, 24(8), 7310-7334. http://dx.doi.org/10.1007/s11356-016-8226-4. PMid:28105592.

Baloch, S., Kazi, T. G., Baig, J. A., Afridi, H. I., \& Arain, M. B. (2020). Occupational exposure of lead and cadmium on adolescent and adult workers of battery recycling and welding workshops: adverse impact on health. The Science of the Total Environment, 720, 137549. http://dx.doi.org/10.1016/j.scitotenv.2020.137549. PMid:32135282.

Başar, E. (2010). Investigation into marine traffic and a risky area in the Turkish straits system: Canakkale strait. Transport, 25(1), 5-10. http://dx.doi.org/10.3846/transport.2010.01.

Beer, S., \& Koch, E. (1996). Photosynthesis of marine macroalgae and seagrasses in globally changing $\mathrm{CO}_{2}$ environments. Marine Ecology Progress Series, 141(1-3), 199-204. http://dx.doi.org/10.3354/ meps141199.

Berik, N., \& Çankırılıgil, E. C. (2019). The elemental composition of green seaweed (Ulva rigida) collected from Çanakkale, Turkey. Aquatic Sciences and Engineering, 34(3), 74-79. http://dx.doi.org/10.26650/ ASE2019557380.

Bonanno, G., \& Orlando-Bonaca, M. (2018). Chemical elements in Mediterranean macroalgae: a review. Ecotoxicology and Environmental Safety, 148, 44-71. http://dx.doi.org/10.1016/j.ecoenv.2017.10.013.

Bonanno, G., Veneziano, V., \& Orlando-Bonaca, M. (2020). Comparative assessment of trace element accumulation and biomonitoring in seaweed Ulva lactuca and seagrass Posidonia oceanica. The Science of the Total Environment, 718, 137413. http://dx.doi.org/10.1016/j. scitotenv.2020.137413. PMid:32105931.

British Nutrition Foundation. (2016). Nutrition requirements. Oxford. Retrieved from https://www.nutrition.org.uk/attachments/article/234/ Nutrition Requirements_Revised Oct 2016.pdf

Calatayud, M., Devesa, V., Virseda, J. R., Barberá, R., Montoro, R., \& Vélez, D. (2012). Mercury and selenium in fish and shellfish: occurrence, bioaccessibility and uptake by Caco- 2 cells. Food and Chemical Toxicology, 50(8), 2696-2702. http://dx.doi.org/10.1016/j. fct.2012.05.028. PMid:22634291.

Circuncisão, A. R., Catarino, M. D., Cardoso, S. M., \& Silva, A. M. S. (2018). Minerals from macroalgae origin: Health benefits and risks for consumers. Marine Drugs, 16(11), 400-430. http://dx.doi. org/10.3390/md16110400. PMid:30360515.

Coenen, M. (2013). Macro and trace elements in equine nutrition. In R. J. Geor, P. A. Harris \& M. Coenen (Eds.), Equine applied and clinical nutrition (pp. 190). Edinburgh: Saunders Elsevier. http:// dx.doi.org/10.1016/B978-0-7020-3422-0.00010-9.

Davarnejad, R., Moraveji, M. K., \& Havaie, M. (2018). Integral technique for evaluation and optimization of $\mathrm{Ni}$ (II) ions adsorption onto regenerated cellulose using response surface methodology. Arabian Journal of Chemistry, 11(3), 370-379. http://dx.doi.org/10.1016/j. arabjc.2015.05.022.

Dembitsky, V. M., Smoum, R., Al-Quntar, A. A., Ali, H. A., Pergament, I., \& Srebnik, M. (2002). Natural occurrence of boron-containing compounds in plants, algae and microorganisms. Plant Science, 163(5), 931-942. http://dx.doi.org/10.1016/S0168-9452(02)00174-7.

Deniz, F., \& Ersanli, E. T. (2018). A natural macroalgae consortium for biosorption of copper from aqueous solution: optimization, modeling and design studies. International Journal of Phytoremediation, 20(4), 362-368. http://dx.doi.org/10.1080/15226514.2017.139338 7. PMid:29584470.
Duinker, A., Roiha, I., Amlund, H., Dahl, L., Lock, E.-J., Kögel, T., Måge, A., \& Lunestad, B. (2016). Potential risks posed by macroalgae for application as feed and food: a Norwegian perspective. Norway: National Institute of Nutrition and Seafood Research.

Esfandiar, N., Nasernejad, B., \& Ebadi, T. (2014). Removal of Mn(II) from groundwater by sugarcane bagasse and activated carbon (a comparative study): application of response surface methodology (RSM). Journal of Industrial and Engineering Chemistry, 20(5), 3726-3736. http://dx.doi.org/10.1016/j.jiec.2013.12.072.

European Food Safety Authority - EFSA. (2013). Dietary exposure to aluminium-containing food additives. Parma, Italy. Retrieved from http://www.efsa.europa.eu/sites/default/files/scientific_output/files/ main_documents/411e.pdf

Feldstein, T., Kashman, Y., Abelson, A., Fishelson, L., Mokady, O., Bresler, V., \& Erel, Y. (2003). Marine molluscs in environmental monitoring III. Trace metals and organic pollutants in animal tissue and sediments. Helgoland Marine Research, 57(3-4), 212-219. http:// dx.doi.org/10.1007/s10152-003-0156-0.

Food and Agriculture Organization of the United Nations - FAO, Codex Alimentarius Commision. (2007). Matters arising from the reports of the commission, codex committees and task forces. Rome: FAO.

Food and Agriculture Organization of the United Nations - FAO, Codex Alimentarius Commision. (2011). Joint FAO/WHO food standards programme codex committee on contaminants in foods fifth session. The Hague: FAO/WHO.

García-Casal, M. N., Pereira, A. C., Leets, I., Ramírez, J., \& Quiroga, M. F. (2007). High 1ron content and bioavailability in humans from four species of marine algae. The Journal of Nutrition, 137(12), 26912695. http://dx.doi.org/10.1093/jn/137.12.2691. PMid:18029485.

Guillard, R. L. L. (1975). Culture of phytoplankton for feeding marine invertebrates. In L. W. Smith \& M. H. Chanley (Eds.), Culture of marine invertebrate animals (pp. 26-60). New York: Plenum Press. http://dx.doi.org/10.1007/978-1-4615-8714-9_3.

Guiry, M. D., \& Guiry, G. M. (2020). AlgaeBase. Galway: National University of Ireland. Retrieved from http://www.algaebase.org

Hiriart-Baer, V. P., Fortin, C., Lee, D. Y., \& Campbell, P. G. C. (2006). Toxicity of silver to two freshwater algae, Chlamydomonas reinhardtii and Pseudokirchneriella subcapitata, grown under continuous culture conditions: Influence of thiosulphate. Aquatic Toxicology, 78(2), 136-148. http://dx.doi.org/10.1016/j.aquatox.2006.02.027. PMid:16621059.

Iglesias-González, J., Sánchez-iglesias, S., Beiras-iglesias, A., MéndezÁlvarez, E., \& Soto-Otero, R. (2017). Effects of aluminium on rat brain mitochondria bioenergetics: an in vitro and in vivo study. Molecular Neurobiology, 54(1), 563-570. http://dx.doi.org/10.1007/ s12035-015-9650-z. PMid:26742531.

Keshtkar, A. R., Moosavian, M. A., Sohbatzadeh, H., \& Mofras, M. (2019). $\mathrm{La}(\mathrm{III})$ and $\mathrm{Ce}(\mathrm{III})$ biosorption on sulfur functionalized marine brown algae Cystoseira indica by xanthation method: Response surface methodology, isotherm and kinetic study. Groundwater for Sustainable Development, 8, 144-155. http://dx.doi.org/10.1016/j. gsd.2018.10.005.

Kravtsova, A., Milchakova, N., \& Frontasyeva, M. (2014). Elemental accumulation in the black sea brown algae Cystoseira studied by neutron activation analysis. Ecological Chemistry and Engineering, 21(1), 9-23. http://dx.doi.org/10.2478/eces-2014-0001.

Kumar, D., Pandey, L. K., \& Gaur, J. P. (2016). Metal sorption by algal biomass: from batch to continuous system. Algal Research, 18, 95109. http://dx.doi.org/10.1016/j.algal.2016.05.026. 
Larkum, A. W. D., \& Wood, W. F. (1993). The effect of UV-B radiation on photosynthesis and respiration of phytoplankton, benthic macroalgae and seagrasses. Photosynthesis Research, 36(1), 17-23. http://dx.doi. org/10.1007/BF00018071. PMid:24318794.

Law, R., Hanke, G., Angelidis, M., Batty, J., Bignert, A., Dachs, J., Davies, I., Denga, Y., Duffek, A., Herut, B., Hylland, K., Lepom, P., Leonards, P., Mehtonen, J., Piha, H., Roose, P., Tronczynski, J., Velikova, V., \& Vethaak, D. (2010). Marine strategy framework directive, contaminants and pollution effects. Luxembourg: Publications Office.

Liu, D. L., Yang, Y. P., Hu, M. H., Harrison, P. J., \& Price, N. M. (1987). Selenium content of marine food chain organisms from the coast of China. Marine Environmental Research, 22(2), 151-165. http:// dx.doi.org/10.1016/0141-1136(87)90033-X.

Lordan, S., Ross, R. P., \& Stanton, C. (2011). Marine bioactives and functional food ingredients: Potential to reduce incidence of chronic diseases. Marine Drugs, 9(6), 1056-1100. http://dx.doi.org/10.3390/ md9061056. PMid:21747748.

Ma, Z., Lin, L., Wu, M., Yu, H., Shang, T., Zhang, T., \& Zhao, M. (2018). Total and inorganic arsenic contents in seaweeds: absorption, accumulation, transformation and toxicity. Aquaculture, 497, 49-55. http://dx.doi.org/10.1016/j.aquaculture.2018.07.040.

MacArtain, P., Gill, C. I. R., Brooks, M., Campbell, R., \& Rowland, I. R. (2007). Nutritional value of edible seaweeds. Nutrition Reviews, 65(12 Pt 1), 535-543. http://dx.doi.org/10.1111/j.1753-4887.2007. tb00278.x. PMid:18236692.

Mendel, R. R. (2013). The molybdenum cofactor. The Journal of Biological Chemistry, 288(19), 13165-13172. http://dx.doi.org/10.1074/jbc. R113.455311. PMid:23539623.

Mišurcová, L., Machů, L., \& Orsavová, J. (2011). Seaweed minerals as nutraceuticals. Advances in Food and Nutrition Research, 64, 371-390. http://dx.doi.org/10.1016/B978-0-12-387669-0.00029-6. PMid:22054962.

Mushtaque, A., \& Chowdhury, R. (2004). Arsenic crisis in Bangladesh. Scientific American, 291(2), 86-91. http://dx.doi.org/10.1038/ scientificamerican0804-86. PMid:15298124.

Nielsen, F. H. (2014). Update on human health effects of boron. Journal of Trace Elements in Medicine and Biology, 28(4), 383-387. http:// dx.doi.org/10.1016/j.jtemb.2014.06.023. PMid:25063690.

Niemiec, M., Wiśniowska-Kielian, B., \& Komorowska, M. (2015). Content of $\mathrm{Ni}$ and $\mathrm{Cr}$ in water and in algae from selected Black Sea bays in the region of Sevastopol. Ecological Chemistry and Engineering. A, 22(4), 433-446.

Nordisk Metodikkomité for Næringsmidler - NMKL. (2007). Nordic Committee on Food Analysis: method no. 186. Lyngby, Danmark.

Oya-Ohta, Y., Kaise, T., \& Ochi, T. (1996). Induction of chromosomal aberrations in cultured human fibroblasts by inorganic and organic arsenic compounds and the different roles of glutathione in such induction. Mutation Research, 357(1-2), 123-129. http://dx.doi. org/10.1016/0027-5107(96)00092-9. PMid:8876688.

Pergantis, S. A., Wangkarn, S., Francesconi, K. A., \& Thomas-Oates, J. E. (2000). Identification of arsenosugars at the picogram level using nanoelectrospray quadrupole time-of-flight mass spectrometry. Analytical Chemistry, 72(2), 357-366. http://dx.doi.org/10.1021/ ac9906072. PMid:10658331.

Pfeiffer, T. Z., Camagakevac, I. S., Maronic, D. S., \& Maksimovic, I. (2017). Regulation of photosynthesis in algae under metal stress. In V. P. Singh, S. Singh, R. Singh \& S. M. Prasad (Eds.), Environment and Photosynthesis a Future Prospect (pp. 261-286). New Delhi: Studium Press.
Raven, J. A., \& Beardall, J. (2003). Carbohydrate metabolism and respiration in algae. In A. W. D. Larkum, S. E. Dougles \& J. A. Raven (Eds.), Photosynthesis in Algae (pp. 205-224). Dordecht: Springer. http://dx.doi.org/10.1007/978-94-007-1038-2_10.

Rodrigues, D., Freitas, A. C., Pereira, L., Rocha-Santos, T. A. P., Vasconcelos, M. W., Roriz, M., Rodríguez-Alcalá, L. M., Gomes, A. M. P., \& Duarte, A. C. (2015). Chemical composition of red, brown and green macroalgae from Buarcos bay in Central West Coast of Portugal. Food Chemistry, 183, 197-207. http://dx.doi.org/10.1016/j. foodchem.2015.03.057. PMid:25863629.

Salehi, P., Tajabadi, F. M., Younesi, H., \& Dashti, Y. (2014). Optimization of lead and nickel biosorption by Cystoseira trinodis (brown algae) using response surface methodology. Clean - Soil, Air, Water, 42(3), 243-250. http://dx.doi.org/10.1002/clen.201100429.

Salgueiro, M. J., Zubillaga, M., Lysionek, A., Sarabia, M. I., Caro, R., De Paoli, T., Hager, A., Weill, R., \& Boccio, J. (2000). Zinc as an esseintial micronutrient: a review. Nutrition Research, 20(5), 737-755. http:// dx.doi.org/10.1016/S0271-5317(00)00163-9.

Sant, N., \& Ballesteros, E. (2020). Photosynthetic activity of macroalgae along a bathymetric gradient: interspecific and seasonal variability. Scientia Marina, 84(1), 7-16. http://dx.doi.org/10.3989/scimar.04995.06A.

Simeonova, A., \& Petkova, S. (2007). Biosorption of heavy metals by marine algae Ulva rigida, Cystoseira barbata and C. crinita. Biosystems Diversity, 15(1), 224-230. http://dx.doi.org/10.15421/010740.

Spada, L., Annicchiarico, C., Cardellicchio, N., Giandomenico, S., \& Di Leo, A. (2012). Mercury and methylmercury concentrations in Mediterranean seafood and surface sediments, intake evaluation and risk for consumers. International Journal of Hygiene and Environmental Health, 215(3), 418-426. http://dx.doi.org/10.1016/j. ijheh.2011.09.003. PMid:21968333.

Stankovic, S., Jovic, M., Stankovic, A. R., \& Katsikas, L. (2014). Heavy metals in seafood mussels. risks for human health. In E. Lichtfouse, J. Schwarzbauer \& D. Robert (Eds.), Environmental chemistry for a sustainable world: nanotechnology and health risk (Vol. 1, pp. 311373). Dordrecht: Springer.

Sun, X., Liu, Z., Jiang, Q., \& Yang, Y. (2019). Concentrations of various elements in seaweed and seawater from Shen'ao Bay, Nan'ao Island, Guangdong coast, China: environmental monitoring and the bioremediation potential of the seaweed. The Science of the Total Environment, 659, 632-639. http://dx.doi.org/10.1016/j. scitotenv.2018.12.364. PMid:31096392.

Swanner, E. D., Planavsky, N. J., Lalonde, S. V., Robbins, L. J., Bekker, A., Rouxel, O. J., Saito, M. A., Kappler, A., Mojzsis, S. J., \& Konhauser, K. O. (2014). Cobalt and marine redox evolution. Earth and Planetary Science Letters, 390, 253-263. http://dx.doi.org/10.1016/j. epsl.2014.01.001.

Swartenbroux, F., Albajedo, B., Angelidis, M., Aulne, M., Bartkevics, V., Besada, V., Bignert, A., Bitterhof, A., Hallikainen, A., Hoogenboom, R., Jorhem, L., Jud, M., Law, R., Cederberg, D. L., McGovern, E., Miniero, R., Schneider, R., Velikova, V., Verstraete, F., Vinas, L., \& Vlad, S. (2010). Marine strategy framework directive, contaminants in fish and other seafood. Luxembourg: Publications Office.

Tabaraki, R., Nateghi, A., \& Ahmady-Asbchin, S. (2014). Biosorption of lead (II) ions on Sargassum ilicifolium: application of response surface methodology. International Biodeterioration \& Biodegradation, 93, 145-152. http://dx.doi.org/10.1016/j.ibiod.2014.03.022.

Tajernia, H., Ebadi, T., Nasernejad, B., \& Ghafori, M. (2014). Arsenic removal from water by sugarcane bagasse: an application of response surface methodology (RSM). Water, Air, and Soil Pollution, 225(7), 1-22. http://dx.doi.org/10.1007/s11270-014-2028-4. 
Takahashi, S., Le, L. T. H., Saeki, H., Nakatani, N., Tanabe, S., Miyazaki, N., \& Fujise, Y. (2000). Accumulation of butyltin compounds and total tin in marine mammals. Water Science and Technology, 42(7-8), 97-108. http://dx.doi.org/10.2166/wst.2000.0557.

Tomza-Marciniak, A., Pilarczyk, B., Marciniak, A., Pilarczyk, R., \& Bakowska, M. (2019). Tin, Sn. In E. Kalisinska (Ed.), Mammals and birds as bioindicators of trace element contaminations in terrestrial environments (pp. 693-708). Switzerland: Springer. http://dx.doi. org/10.1007/978-3-030-00121-6_19.

Ungureanu, G., Santos, S., Boaventura, R., \& Botelho, C. (2018). Biosorption of antimony by brown algae S. muticum and A. nodosum. Environmental Engineering and Management Journal, 14(2), 455-463.

Vizetto-Duarte, C., Custódio, L., Barreira, L., Silva, M. M., Rauter, A. P., Albericio, F., \& Varela, J. (2016). Proximate biochemical composition and mineral content of edible species from the genus Cystoseira in Portugal. Botanica Marina, 59(4), 251-257. http://dx.doi.org/10.1515/bot-2016-0014.
Wang, Q., Zuo, Y., Chen, T., Zheng, W., \& Yang, Y. (2019). Effects of selenium on antioxidant enzymes and photosynthesis in the edible seaweed Gracilaria lemaneiformis. Journal of Applied Phycology, 31(2), 1303-1310. http://dx.doi.org/10.1007/s10811-018-1647-3.

Yokel, R., Allen, D., \& Meyer, J. (1994). Studies of aluminum neurobehavioral toxicity in the intact mammal. Cellular and Molecular Neurobiology, 14(6), 791-808. http://dx.doi.org/10.1007/ BF02088685. PMid:7641237.

Zarei, S., \& Niad, M. (2017). Cystoseira myricaas for mercury (II) uptake: isotherm, kinetics, thermodynamic, response surface methodology and fuzzy modeling. Journal of the Taiwan Institute of Chemical Engineers, 81, 247-257. http://dx.doi.org/10.1016/j.jtice.2017.10.010.

Zou, D., Gao, K., \& Xia, J. (2011). Dark respiration in the light and in darkness of three marine macroalgal species grown under ambient and elevated $\mathrm{CO}_{2}$ concentrations. Acta Oceanologica Sinica, 30(1), 106-112. http://dx.doi.org/10.1007/s13131-011-0096-5. 